Research Article

\title{
An Analysis of Construction Failure Factors to Stakeholder Coordinating Performance in the Finishing Phase of High-Rise Building Projects
}

\author{
Viet T. Nguyen $\left(\mathbb{D},{ }^{1}\right.$ Sy T. Do $\mathbb{D}^{2,3}$ Nhat M. Vo, ${ }^{4}$ Thu A. Nguyen, ${ }^{2,3}$ and Son V. H. Pham ${ }^{2,3}$ \\ ${ }^{1}$ Faculty of Civil Engineering, Industrial University of Ho Chi Minh City, Ho Chi Minh City, Vietnam \\ ${ }^{2}$ Department of Construction Engineering and Management, Faculty of Civil Engineering, \\ Ho Chi Minh City University of Technology (HCMUT), Ho Chi Minh City, Vietnam \\ ${ }^{3}$ Vietnam National University, Ho Chi Minh City, Vietnam \\ ${ }^{4}$ AnCons Construction Technique Co. Ltd., Ho Chi Minh City, Vietnam \\ Correspondence should be addressed to Sy T. Do; sy.dotien@hcmut.edu.vn
}

Received 9 November 2020; Revised 15 December 2020; Accepted 18 December 2020; Published 29 December 2020

Academic Editor: Valeria Vignali

Copyright ( 92020 Viet T. Nguyen et al. This is an open access article distributed under the Creative Commons Attribution License, which permits unrestricted use, distribution, and reproduction in any medium, provided the original work is properly cited.

\begin{abstract}
A poorly coordinated performance among stakeholders in the finishing phase can impair the performance of a high-rise building project. Therefore, it is necessary to analyze construction failure factors (CFFs) to stakeholder coordinating performance (SCP) in the finishing phase of high-rise building projects and to uncover their underlying relationships. CFFs to SCP in construction projects, especially in the finishing phase of high-rise building projects, have not yet been discovered. The study identified $30 \mathrm{CFF}$ to the SCP and ranked them according to the perspective of the stakeholders, including owners/consultants and contractors/ subcontractors. Additionally, four factors of the CFFs, namely, traditional adversarial relationship, poor project planning and organization, incompetent parties, and delays of parties toward construction works were extracted by the factor analysis method. This study fills the gap in knowledge related to the coordination performance in construction projects. The findings could help stakeholders to enhance their coordinating performance in high-rise building projects.
\end{abstract}

\section{Introduction}

High-rise building projects are strongly developing in modern urban areas to ensure the huge demand for living space. Accordingly, high-rise building will continue to be the inevitable housing trend of the real estate market in large cities. Many real estate investors and construction contractors are concentrating resources and funds to meet these demands. A high-rise building is one of the very complex projects, with the participation of many parties involved for a long period of time[1]. Many high-rise construction projects face many failure issues related to quality, progress, cost, and safety [1]. There are numerous studies identifying failure factors that affect the overall goals of a high-rise building projects such as poor performance of the contractor $[2,3]$; inappropriate planning [3-5]; drastic design changes
$[2,3,6,7]$; lack of stakeholder commitment $[3,5]$; and unresolved spatial problem [8]. In order to avoid problems with project failures, it requires the smooth and synchronous coordination of many stakeholders such as state agency, owners, project management units, consultants, contractors, suppliers, and users throughout the project implementation $[9,10]$. In any high-rise building projects, the finishing phase that involves a large number of stakeholders at the same time with the simultaneous deployment of different work items can be considered as one of the most complex phases. Indeed, according to research by Brodetskaia et al. [11], interior and finishing works workflow tasks in the finishing phase include (1) structural handover, (2) drywall, (3) plumbing, (4) electrical activities, (5) HVAC, (6) drywall (reentrant), and (7) tiling works. Another study by Sacks et al. [12] on a flow chart of construction projects with 
optimal production flow is as follows: (1) partitions, (2) electrical, (3) plaster, (4) sprinklers, (5) plumbing, (6) waterproofing, and (7) tiling. Having the participation of various stakeholders in order in the same region can lead to overlapping, interruption, or delayed work for the parties [13]. The main reason may be due to the failure of the preceding contractors to complete on time, or the poor quality to hand over to the subsequent contractors [14]. Moreover, the number of people and materials and the amount of equipment rise dramatically in the finishing phase, so the project's level of effort reaches its peak. Besides, at the finishing phase, the phase of intersection between the two main phases of the project (the execution phase and hand-over phase) is the period with the greatest risk of impact on the cost and progress of the project.

Since the number of study works on the finishing phase of high-rise building projects is considerably low. This paper aims at analyzing the construction failure factors (CFFs) to stakeholder coordinating performance during the finishing phase of high-rise building projects, as well as discovering their underlying relationships. In this study, the CFFs are factors that impair the stakeholder coordinating performance.

\section{Literature Review}

2.1. Finishing Phase of High-Rise Building Projects. The finishing stage is assumed as a stage that includes painting work, wooden work, aluminum work, and metalwork whereas the painting work consists of interior wall and ceiling, exterior wall, metal, and wooden surface. Wooden work is a sequence of works as a door shutter and door frame. Aluminum work includes window work, door work, and curtain wall work. Metalwork comprises window grill, railing, and gate. Besides, a recent study by Brodetskaia et al. [11] proves that there are two main works (i.e., MEP systems and interior finishing works) that needed to complete a project with the characteristics of uncertain, unstable, and wasting of various kinds. They are MEP systems and interior finishing works, accounted for the major parts of the cost and schedule of most constructions. They are not technically obliged to be performed floor by floor and they are executed by numerous subcontractors. Higher degrees of variety as an outcome of a vulnerability in supply chains, varieties in work quantities, clients' decision changes, and lack of consistency of the production capacity of subcontracting exchanges are exhibited by the finishing stage in the project [11]. Moreover, the differences in trades and unpredictable subcontractors' production capacities cause variability that is detrimental to smooth workflow, leading to the quantities of work varying from space to space [15].

2.2. Coordination in Construction. Chang and Shen [16] define coordination as a business management approach by collaborating interdependently between people or organizations. The main concern and principle of coordination focus on the organization, interdependent links, relationships, information exchange, and common objectives between involved parties [17].

Studies of coordination in construction have attracted many researchers. A large number of studies have identified and assessed construction coordination activities influencing the successful completion of a construction project [18-20]. Other studies have focused on investigating causes/ factors affecting coordination in construction projects $[17,21,22]$. Some researchers have paid attention to a framework for coordination processes or factors and their relationships with construction project performance $[23,24]$. Based on a comprehensive review of the literature, it can be seen that most of the previous studies identified construction coordination activities and factors affecting coordination in construction projects or assessed the impact of coordination factors on project performance and completion. The CFFs to stakeholder coordinating performance in construction projects, especially in the finishing phase of high-rise building projects, have not yet been discovered. Hence, this study attempts to fill this gap.

\subsection{Construction Failure Factors to Stakeholder Coordinating} Performance in the Finishing Phase of High-Rise Building Projects. So far, studies on the CFFs to coordinating performance in construction projects among stakeholders have been very limited. The CFFs to stakeholder coordinating performance can be considered as an aspect of failure and abandonment factors of construction projects. Therefore, this study conducted a comprehensive literature review on factors influencing the failure and abandonment of construction projects to identify the CFFs to stakeholder coordinating performance in the finishing phase of high-rise building projects.

There are some studies on factors causing the failure of construction projects. For instance, Alaloul et al. [24] investigated failure factors of a public-private partnership (PPP) in the UAE and found that lack of appropriate skills, poor communications between private partners, high project value, and high participation cost were the most critical failure factors. However, a study by Trangkanont and Charoenngam [7] on critical failure factors of PPP low-cost housing program in Thailand showed that critical failure factors were ineffective change management of public clients, undermined organizational culture and staff's behavior of public clients, inappropriate contractors, poor bidding documents, difficulties of low-income groups, political risks, economic crisis, and limitations of housing finance. Another study was also performed to identify failure factors of road infrastructure PPP projects in India [25]. The results of this study concluded that public protest, political parties, influence of higher authorities, force majeure, and maintenance cost overruns were the most responsible factors for the failure of road PPPs in the planning stage, development stage, procurement stage, construction stage, and operation and maintenance stage, respectively, while in the study of Ikediashi et al. [26] in Saudi Arabia, poor risk management was found to be the paramount failure factor for infrastructure projects, followed by budget overruns and poor 
communication, respectively. In addition, 24 failure factors were categorized into eight components by the factor analysis technique, namely, shortcomings in project management, lack of project team's commitment, constraints imposed by stakeholders, risk problems, financial and schedule problems, ethical issues, government's interference, and user requirement.

In the Vietnamese construction industry, Nguyen and Chileshe [3] carried out a study to revisit failure factors of construction projects. They found that disregarding the planning stage, lack of experience in implementing large projects, designers' poor competence and frequent change of design, lack of knowledge and ability to manage construction projects, owner's financial difficulties, contractors' poor performance, lack of project management and organization systems, corruption and bribery in construction projects, delays in payment, and economic instability and high inflation are the top ten most critical failure factors. Frequent change of design, contractors' poor performance, payment delays, and owner's financial difficulties were also found to be the most critical failure factors in the study of Gamil and Abdul Rahman [2] on factors contributing to construction failure in Yemen. Other critical failure factors identified by Gamil and Abdul Rahman [2] included poor construction management, continuous suspension of work, lack of raw materials, engineers and construction workers with low salary, and poor financial control and management. Earlier, Gamil et al. [4] had studied failure factors of Yemeni mega construction projects and showed that poor planning, ineffective coordination and communication, and lack of advanced technology were the most significant failure factors. Meanwhile, in the Ghanaian government construction projects, the most important factors causing failure were political interferences, partisan politics, payment delays, bureaucracy, corruption, poor supervision, poor planning, lack of commitment by project leaders, implementing more projects than the fund of the government, and change in government [5]. Damoah and Kumi [5] also grouped the failure factors into four key components, including leadership, management and administrative practices, resources, and external forces. In large transportation projects in Greece, Papaioannou and Peleka [27] identified key failure factors such as serious lack of know-how and experience, vague relations among the involved parties, small market size and structure, and oligopolistic traits of the market. In addition, Montequin et al. [6] discovered failure causes in different types of projects with data collected from many different countries. They found that vague specifications, frequent changes of original requirements, inaccurate time estimations, and incomplete project requirements were the most frequent failure causes.

Furthermore, other researchers have focused on factors affecting the abandonment of construction projects. Alao and Jagboro [28] identified the most significant causes of project abandonment in the Nigerian public tertiary educational institutions projects such as payment delays, fund mismanagement, insufficient budget allocation, insufficient finance, contractors' inflation, and bankruptcy. They also explored four significant components, including stakeholders' response capacity, poor financial management, improper planning and monitoring, and unexpected occurrences. In a study also performed in Nigeria with a different kind of project, there were some similar results with the study of Alao and Jagboro [28] that owners' insufficient finance, contractors' bankruptcy, and business failure were considered as the significant factors to the failure and abandonment of multistorey building projects [29]. Other significant factors found in the study of Adebisi et al. [29] were improper planning at the preconstruction phase, improper scheduling of building project activities, structural failure during construction, and qualified professionals' lack of involvement. The failure and abandonment factors were then grouped into five components, namely, capability of human resources, contractor selection and variation, planning and structural quality, insecurity and variation, and force majeure and political risk [29]. By using the factor analysis and structural equation modeling techniques, Damoah et al. [30] explored factors influencing school building construction projects abandonment in Ghana and found that political leadership was the most significant construct of factors, followed by poor administrative/institutional practices, poor resource/funding, cultural factors, and external forces.

In sum, the majority of previous studies were carried out in developing countries such as Vietnam, Thailand, India, Yemen, Ghana, and Nigeria. This result shows that failure factors of construction projects in developing countries have attracted the interest of many researchers. This is probably because construction projects in developing countries face more problems when compared to developed countries. Ofori [31] showed that construction industries in developing countries faced many problems such as resource constraints, lack of technical and managerial capability, lack of knowledge, short-term orientation and lack of focus on construction, falling exchange rates and rising inflation. These problems were found to be critical failure factors of construction projects in previous studies (Nguyen and Chileshe [3]; Damoah and Kumi [5]; Trangkanont and Charoenngam [7]; Alaloul et al. [24]; and Alao and Jagboro [28]). The failure factors to construction projects differ from one country to another, due to different characteristics of each country such as culture, economic conditions, or technology advancement. Based on previous studies on the failure and abandonment factors of construction projects, this study filtered out 22 CFFs (Table 1) to stakeholder coordinating performance in the finishing phase of high-rise building projects.

\section{Research Methodology}

The research framework is shown in Figure 1. This study combines qualitative analysis and quantitative analysis. In the qualitative phase, based on previous studies, the study identified a set of potential CFFs to stakeholder coordinating performance (SCP) in the finishing phase of high-rise building projects. The set of potential CFFs was the basis to design a preliminary questionnaire for the study. Afterwards, a pilot test was conducted to gather experts' 
TABLE 1: List of potential construction failure factors to stakeholder coordinating performance.

\begin{tabular}{lr}
\hline Code & Potential construction failure factors \\
\hline F1 & $\begin{array}{c}\text { Lack of capability of owner's project managemen } \\
\text { unit }\end{array}$ \\
F2 & Design changes by owner's request \\
F3 & Scope changes \\
F4 & $\begin{array}{c}\text { Delays in approving documents from } \\
\text { consultants/owner representatives }\end{array}$ \\
F5 & Design errors and omissions \\
F6 & Lack of specifications in design drawings \\
F7 & Consultants' lack of capability
\end{tabular}

Contractors' lack of experience and competence

$$
\begin{gathered}
\text { Unclear scope of work } \\
\text { Lack of commitment from project stakeholders } \\
\text { Lack of comprehensiveness and adequacy of } \\
\text { contract documentation } \\
\text { Consultants' lack of flexibility (rigidity) in } \\
\text { problem-solving } \\
\text { Unforeseen accidents during construction } \\
\text { Delays in handing over works between } \\
\text { contractors } \\
\text { Reworks }
\end{gathered}
$$

Poor planning and scheduling

Improper construction methods of contractors Overlapping construction sequences

Insufficient communication between project stakeholders

Handover of unclear/unready construction grounds to other contractors

Delays in problem-solving from owner Ambiguity of responsibility in solving on-site problems

Lack of respect and trust between project stakeholders

Dishonesty between project stakeholders Regular transfer/replacement of key personnel Complicated procedures and regulations Lack of work-related support between project stakeholders

Unreasonable pressure from consultants and owner/owner representatives

Disputes between project stakeholders

Privacy policies of project stakeholders
Sources

El-sokhn and Othman [32]; Nguyen and Chileshe [3]; Ikediashi et al. [26]; Gamil

et al. [4]; Trangkanont and Charoenngam [7]; Montequin et al. [6]; Alhashemi [33]; Damoah and Kumi [5]; Papaioannou and Peleka [27]; Alao and Jagboro [28]; Adebisi et al. [29]; Damoah et al. [30]

Nguyen and Chileshe [3]; Ikediashi et al. [26]; Gamil and Abdul Rahman [2]; Trangkanont and Charoenngam [7]; Montequin et al. [6]; Adebisi et al. [29] Gamil and Abdul Rahman [2]; Trangkanont and Charoenngam [7]; Montequin et al. [6]; Nallathiga et al. [25]; Damoah and Kumi [5]; Alao and Jagboro [28];

Adebisi et al. [29]

\section{Expert opinions}

El-sokhn and Othman [32]; Ikediashi et al. [26]; Gamil and Abdul Rahman [2]; Alao and Jagboro [28]

Montequin et al. [6]; Damoah and Kumi [5]; Alao and Jagboro [28]; Damoah et al. [30]

El-sokhn and Othman [32]; Nguyen and Chileshe [3]; Gamil and Abdul

Rahman [2]; Trangkanont and Charoenngam [7]; Alhashemi [33]; Damoah and Kumi [5]; Papaioannou and Peleka [27]; Alao and Jagboro [28]; Adebisi et al. [29]; Damoah et al. [30]

El-sokhn and Othman [32]; Nguyen and Chileshe [3]; Gamil and Abdul

Rahman [2]; Gamil et al. [4]; Trangkanont and Charoenngam [7]; Nallathiga et al. [25]; Alhashemi [33]; Damoah and Kumi [5]; Papaioannou and Peleka

[27]; Alao and Jagboro [28]; Adebisi et al. [29]; Damoah et al. [30] El-sokhn and Othman [32]; Damoah and Kumi [5] Damoah and Kumi [5]

Gamil and Abdul Rahman [2]; Gamil et al. [4]; Trangkanont and Charoenngam [7]; Nallathiga et al. [25]

Expert opinions

Montequin et al. [6]; Nallathiga et al. [25]

Expert opinions

Nguyen and Chileshe [3]

El-sokhn and Othman [32]; Nguyen and Chileshe [3]; Ikediashi et al. [26]; Gamil and Abdul Rahman [2]; Gamil et al. [4]; Damoah and Kumi [5]; Alao and Jagboro [28]; Damoah et al. [30]

Nguyen and Chileshe [3]; Ikediashi et al. [26]; Gamil et al. [4] Expert opinions

El-sokhn and Othman [32]; Ikediashi et al. [26]; Gamil and Abdul Rahman [2]; Gamil et al. [4]; Montequin et al. [6]; Nallathiga et al. [25]; Alhashemi [33]; Damoah and Kumi [5]; Alao and Jagboro [28]

Nguyen and Chileshe [3]; Nallathiga et al. [25]

$$
\begin{aligned}
& \text { Expert opinions } \\
& \text { Expert opinions }
\end{aligned}
$$

Gamil and Abdul Rahman [2]; Alhashemi [33]; Papaioannou and Peleka [27]

Ikediashi et al. [26]; Gamil et al. [4]

Montequin et al. [6]; Damoah and Kumi [5]; Damoah et al. [30]

Trangkanont and Charoenngam [7]

Expert opinions

Damoah and Kumi [5]

Gamil and Abdul Rahman [2]; Montequin et al. [6]; Alao and Jagboro [28] Expert opinions 


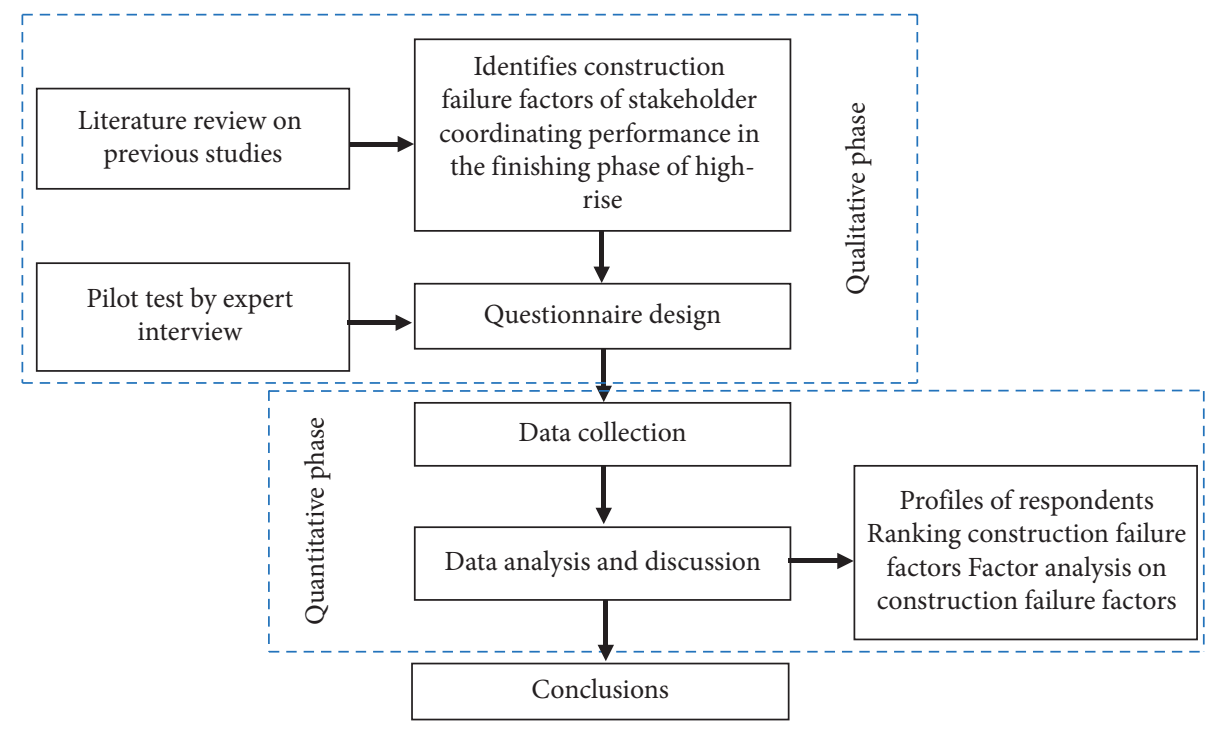

FIGURE 1: Research framework.

comments on the preliminary questionnaire. Consequently, a final questionnaire was completed to collect data for the study, explained in the next paragraphs. In the quantitative phase, the study performed analysis on data, including profiles of respondents, ranking CFFs, and factor analysis on CFFs as well as discussing analysis results. Differences in assessing CFFs among stakeholders, specially, are expected to be clarified and the underlying relationships between CFFs are also discovered.

In the pilot test process, five experts (i.e., three project managers from contractors, one project director from consultant, and one owner representative) with at least ten years of experience in high-rise building construction were invited to check the concepts of the preliminary questionnaire. They were also asked to add or remove any CFFs if they find that this is appropriate for problems of stakeholder coordinating performance in the finishing phase of high-rise building projects. As a result, the experts added eight new CFFs, including "delays in approving documents from consultants/owner representatives," "consultants' lack of flexibility in problem-solving," "delays in handing over works between contractors," "overlapping construction sequences," "delays in problem-solving from owner," "ambiguity of responsibility in solving on-site problems," "lack of work-related support between project stakeholders," and "privacy policies of project stakeholders" (Table 1). The final questionnaire consisted of 30 CFFs to SCP in the finishing phase of high-rise building projects.

The questionnaire was distributed to respondents from clients/project management units, consultants, and contractors who were mainly involved in the finishing phase of high-rise building projects through a direct delivery. The questionnaire includes three parts. The first part of the questionnaire introduced the respondents to the purpose of the survey. The second part was designed to collect the general information of the respondents. Eventually, in the final part, the respondents were asked to assess the degree of the influence of the 30 CFFs on SCP in the finishing phase of high-rise building projects. The study used a five-point Likert scale ranging from 1 (not significant) to 5 (extremely significant) to gather the respondents' views on assessing the CFFs.

After about three months, 188 questionnaires were received in Vietnam, but only 126 valid responses were valid and without responses with experience years less than 3 . Eliminating the responses with experience years less than 3 in the study was to increase the reliability of the data. The response rates from different groups were $54.8 \%$ for owners/ consultants and $45.2 \%$ for contractors (Table 2). The proportions of the respondents in terms of the number of experience years involved in construction were as follows: between 3 and 5 years (39.7\%), between 5 and 10 years $(42.1 \%)$, and 10 years or more $(18.3 \%)$.

\section{Assessing Construction Failure Factors to Stakeholder Coordinating Performance in the Finishing Phase of High-Rise Building Projects}

Based on the overall respondents' opinions (Table 3), 20 of $30 \mathrm{CFFs}$ are considered significant (mean $\geq 3.50)$ [34]. There are seven most significant CFFs that have a mean value greater than 4.00, namely, contractors' lack of experience and competence (F8), overlapping construction sequences (F18), consultants' lack of capability (F7), insufficient communication between project stakeholders (F19), poor planning and scheduling (F16), delays in handing over works between contractors (F14), and lack of capability of owner's project management unit (F1). Thus, they are considered to be the most significant CFFs to SCP in the finishing phase of high-rise building projects in Vietnam.

"Contractors' lack of experience and competence (F8)" was ranked first by both owners/consultants and contractors/subcontractors. Regarding the success or failure of a construction project, contractor's experience and 
TABLE 2: Questionnaire return rate.

\begin{tabular}{lcccc}
\hline Stakeholder & Questionnaire distributed & Response received & Response rate (\%) & Proportion (\%) \\
\hline Owners/consultants & 100 & 69 & 69.0 & 54.8 \\
Contractors* & 88 & 57 & 64.8 & 45.2 \\
Total & 188 & 126 & 67.0 & 100.0 \\
\hline
\end{tabular}

${ }^{*}$ The contractors include the main contractors and subcontractors.

competence have proven to be crucial $[2,3,29,35]$. In this study, it is of paramount influence to stakeholder coordinating performance in the finishing phase of high-rise building projects. This shows the important role of the contractor in the finishing phase. Contractors directly perform the work on site, so it can be said that they are the center of coordination among stakeholders. Hence, it is understandable why this construction failure factor occupies the highest-ranking position. This result seems to show that there is a relationship between stakeholder coordinating performance and the success/failure of a project stemming from contractors' experience and competence. It means that a well-coordinated performance among stakeholders can enhance the success of a project and vice versa.

The second-ranked construction failure factor is overlapping construction sequences (F18). Traditionally, the overlapping activities that are implemented in sequence can significantly reduce project time. However, the control of construction sequences is not easy in the finishing stage when there are too many risk factors related to many participating units, handing over construction sites, materials, people, and so on. Unplanned overlapping may not speed up the project but can also affect the excessive design and construction rework [36]. The overlapping activities include the number of tasks performed concurrently and can require more resources. This requires the main contractor to manage the interfaces between their subcontractors well in the finishing stage. Moreover, it also requires flexibility and cooperation between subcontractors. In practice, however, subcontractors may lack cooperation and work together and focus only on their own personal interests. As a result, it may be difficult for the main contractor to manage the interfaces between their subcontractors, thereby leading a poor coordination performance.

The third-ranked construction failure factor is consultants' lack of capability (F7). This is consistent with the results from the previous study by Long et al. [37]. Indeed, Vietnam currently lacks qualified consultants for handling large projects, especially the finishing phase with multistakeholder participation in the high-rise building project. Each of the participants is considered as a link in the coordination chain, so their lack of capacity is likely to slow down the pace of coordination between them. Consultants' lack of capability is highly rated as a significant influence on coordination performance perhaps because of their role in handling information and dealing with project problems. They lack the ability to process information, processing information slowly whereby they will influence other members in the coordination process.

Ineffective communication between stakeholders is considered to be one of the main CFFs to coordination performance in the finishing phase of high-rise building projects, ranking the $4^{\text {th }}$. Insufficient or incorrect communication will make stakeholders confused. Each of the stakeholders will understand differently; this causes incompatibility among stakeholders in the coordination process. As a result, stakeholders will catch the coordination rhythm incorrectly, which may lead to poor coordination among stakeholders. Moreover, poor communication between parties can lead to failure [5], delays [38, 39], disputes [28], and contract termination [4]. The work of Ihuah and Benobo [40], however, showed that the communication gap is not critical but a significant cause of project abandonment. Based on the research of Gamil et al. [4], ineffective means and lack of technology are the main cause of ineffective project communication flow during construction. It is logical that there should be a way for the parties to communicate effectively. Currently, many platforms or software have been developed to support communication between parties such as BIM 360, BIM sight, and Solibri. For example, Solibri program is a communication and coordination solution for all stakeholders, both on site and in the office; data is consistent and updated continuously throughout the life of the project.

Poor planning and scheduling were also given high ratings in degree of influence to stakeholder coordinating performance during the finishing phase of high-rise construction projects. This accords with earlier research $[2-5,28,30]$. Obviously, poor planning and scheduling affect the stakeholder coordinating performance. For instance, the poor planning and scheduling from the main contractor can lead to a lack of activities or improper arranged activities. Therefore, subcontractors may do their jobs at the wrong time, which makes the coordination process more complicated and creates unexpected overlapping activities among them. As a matter of course, it leads to poor coordination between the main contractor and their subcontractors.

When considering the rankings among two groups of respondents including the owners/consultants and the contractors/subcontractors, $16 \mathrm{CFFs}$ are considered significant by the owners/consultants, whereas 24 CFFs are rated significant by the contractors/subcontractors. Interestingly, the respondents from the contractors/subcontractors generally rank CFFs higher than the owners/consultants (Figure 2). This result may be in line with reality. Contractors are the intermediate tie to link the upstream (owners, consultants) and downstream (subcontractors, suppliers) in the supply chain relationship network, so they have more interactions than other stakeholders. Therefore, they may be very interested in the coordination among the stakeholders.

In order to clarify the different perceptions of both groups on the criticality of CFFs affecting stakeholder 


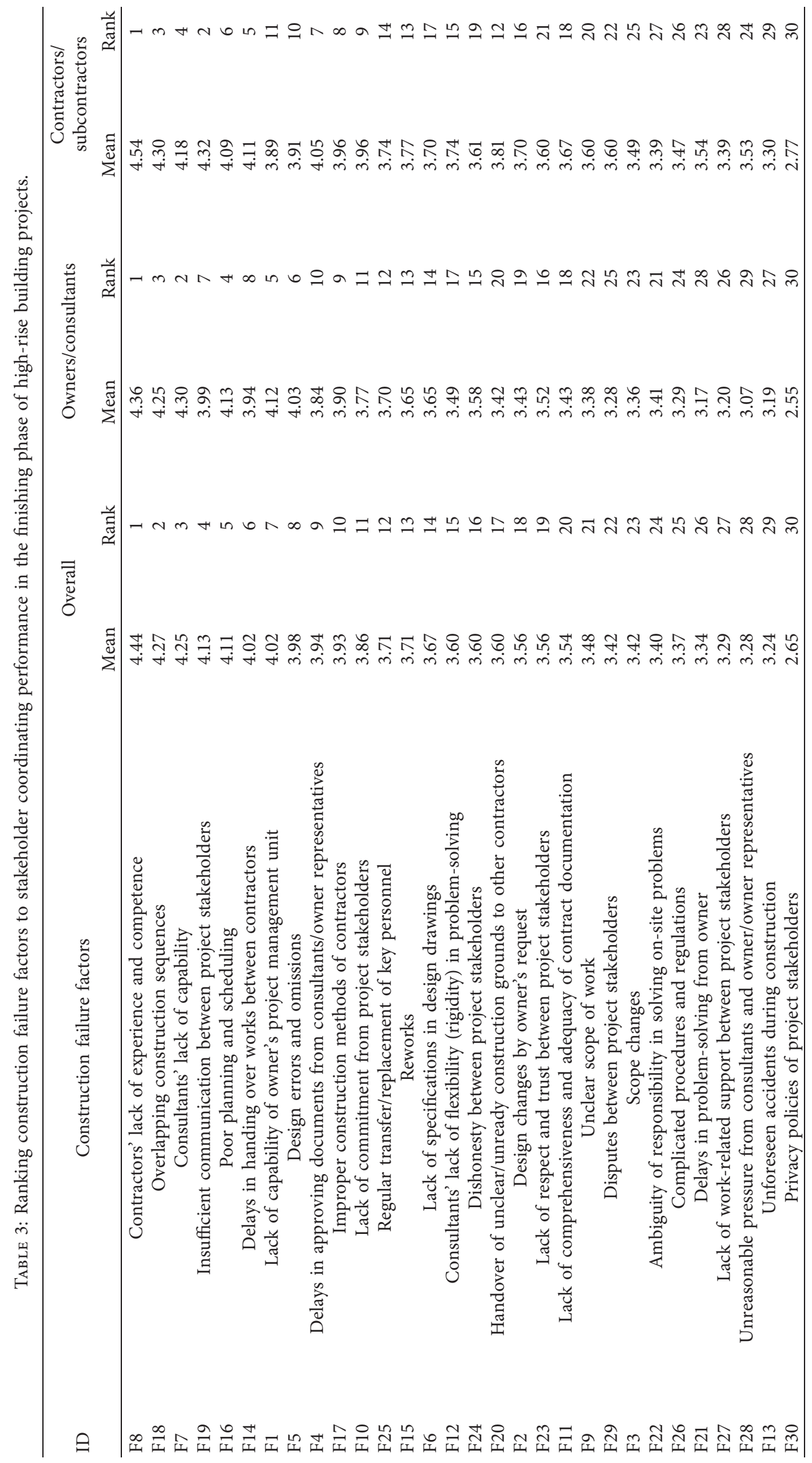




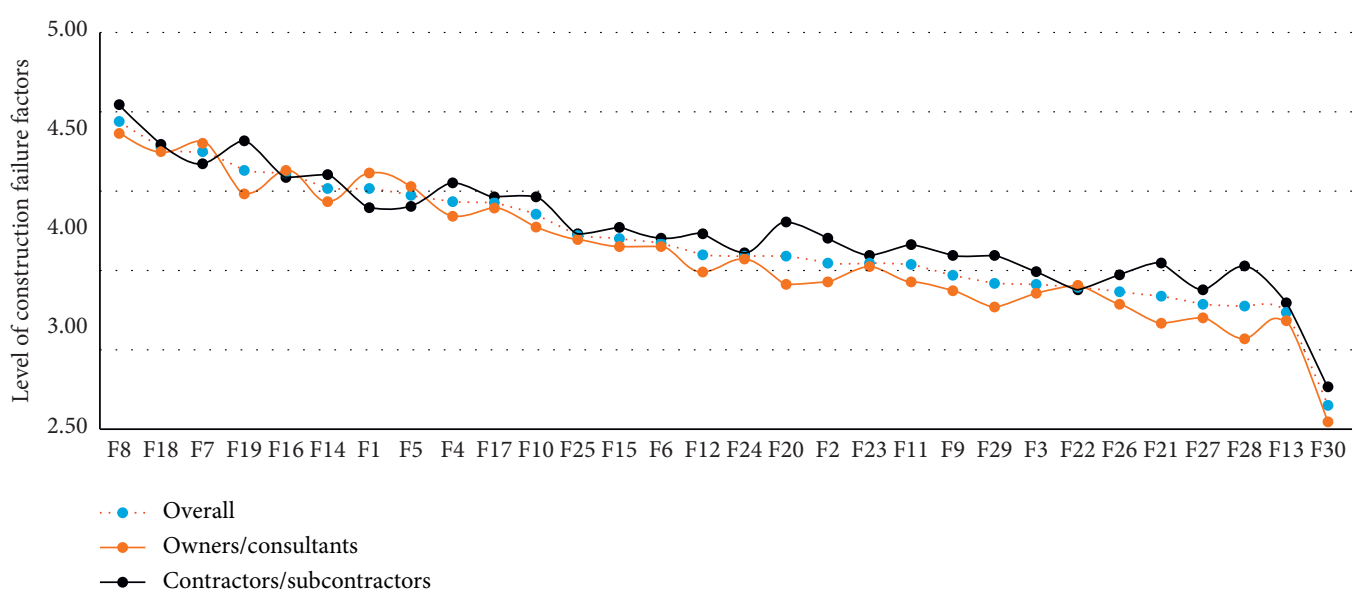

FIgURE 2: Cross-comparison of failure factors among groups.

coordinating performance, their perceptions are compared through the independent sample $t$-test method (at $\alpha=5 \%$ ). The null hypothesis is that there is no significant difference between the owners/consultants and the contractors/subcontractors' perceptions. The factors with significant differences between the owners/consultants and the contractors/subcontractors under an independent $t$-test are displayed in Table 4, pertaining to the CFFs affecting stakeholder coordinating performance in the finishing phase of high-rise building projects.

Some disparities are found in the rankings among the owners/consultants and the contractors/subcontractors based on an independent $t$-test (Table 4). The survey data reveal that only four CFFs (13.3\%) show significantly different construction failure perceptions of groups, as shown in Table 4. These differences result from the fact that the owners/consultants and the contractors/subcontractors are independent entities with different viewpoints and perspectives about CFFs affecting stakeholder coordinating performance. For example, the owners/consultants usually more focus on the CFFs related to the general goals of construction projects as time, cost, quality, and safety. In contrast, the contractors/subcontractors are more concerned about the coordination among stakeholders such as communication, handover of construction grounds, and disputes.

The first striking disparity is detected in item F28 "unreasonable pressure from consultants and owner/owner representatives." The owners/consultants rank it the twentyninth while the contractors/subcontractors rank it the twenty-fourth. The unreasonable pressure that the contractors/subcontractors receive from the owners/consultants is an inevitable problem in the construction phase. The owners/consultants create the unreasonable pressure to speed up the construction progress of the contractors/ subcontractors. They may see this problem as what they have to do and think that the contractors/subcontractors are used to dealing with such a problem. Hence, their perception can argue that this problem will not significantly affect the coordination between them and the contractors/subcontractors. Conversely, the contractors/subcontractors may believe that the unreasonable pressure makes them tired and uncomfortable in the process of coordinating with the owners/consultants. Therefore, they emphasize this problem more than the owners/consultants in the coordination among stakeholders. A similar result on item F29 "disputes between project stakeholders": the contractors/subcontractors rate this factor higher than the owners/consultants. The finishing phase of high-rise building projects involves the participation of many different contractors/subcontractors. Therefore, disputes between any two participants could affect the others, especially subcontractors. Disputes may cause subcontractors to delay receiving payments from the main contractors or owners because of the delay of a sequence of works involving disputes. This problem seriously affects subcontractors with poor financial capacity which exists in many high-rise building projects. Perhaps for this reason, the contractors/subcontractors rank item F29 in a higher order than the owners/consultants.

Another disparity is observed in item F19 "insufficient communication between project stakeholders" (ranked second by the contractors/subcontractors and seventh by the owners/consultants). As mentioned above, this result is probably because of the position of contractors in the supply chain. The contractors receive a lot of information both from upstream and downstream, so they emphasize effective communication among the parties in the finishing phase. The owners/consultants rank "lack of capability of owner's project management unit" as one of the five most significant CFFs (ranked fifth), whereas the contractors/subcontractors rank it the eleventh. This indicates that, from the contractors' perspective, the project management unit's role does not seem to be important in the coordination among stakeholders in the finishing phase, while the project management unit can be a crucial coordinator during the project from the owners' point of view. It is understandable when stakeholders always appreciate their role in the project.

A similar perception is observed in item F20 "handover of unclear/unready construction grounds to other contractors," which is ranked the twentieth by the owners/ consultants and the twelfth by the contractors/subcontractors, respectively. This result reflects properly the fact that 
TABLE 4: Factors with significant different construction failure perceptions of groups under $t$-test.

\begin{tabular}{|c|c|c|c|c|c|c|c|c|c|}
\hline \multirow{2}{*}{\multicolumn{2}{|c|}{ Construction failure factors }} & \multicolumn{3}{|c|}{$\begin{array}{c}\text { Levene's test for equality of } \\
\text { variances }\end{array}$} & \multicolumn{5}{|c|}{$t$-test for equality of means } \\
\hline & & \multirow{2}{*}{ Assumption } & \multirow{2}{*}{$\mathrm{F}$} & \multirow{2}{*}{ Sig. } & \multirow{2}{*}{$\mathrm{t}$} & \multirow{2}{*}{$\mathrm{df}$} & \multirow{2}{*}{$\begin{array}{l}\text { Sig. } \\
\text { (2-Tailed) }\end{array}$} & \multirow{2}{*}{$\begin{array}{l}\text { Mean } \\
\text { Diff. } \\
\left({ }^{*}\right)\end{array}$} & \multirow{2}{*}{$\begin{array}{l}\text { Std. } \\
\text { Error } \\
\text { Diff. }\end{array}$} \\
\hline $\begin{array}{l}\text { Own } \\
\text { versu } \\
\text { subce }\end{array}$ & $\begin{array}{l}\text { tants } \\
\text { ors/ }\end{array}$ & & & & & & & & \\
\hline F28 & $\begin{array}{l}\text { Unreasonable pressure from } \\
\text { consultants and owner/owner } \\
\text { representatives }\end{array}$ & $\begin{array}{l}\text { Equal variances } \\
\text { assumed }\end{array}$ & 1.730 & 0.191 & -3.102 & 124 & 0.002 & -0.454 & 0.146 \\
\hline F20 & $\begin{array}{l}\text { Handover of unclear/unready } \\
\text { construction grounds to other } \\
\text { contractors }\end{array}$ & $\begin{array}{l}\text { Equal variances } \\
\text { assumed }\end{array}$ & 0.289 & 0.592 & -2.803 & 124 & 0.006 & -0.387 & 0.138 \\
\hline F19 & $\begin{array}{l}\text { Insufficient communication } \\
\text { between project stakeholders }\end{array}$ & $\begin{array}{l}\text { Equal variances } \\
\text { assumed }\end{array}$ & 0.130 & 0.719 & -2.468 & 124 & 0.015 & -0.330 & 0.134 \\
\hline F29 & $\begin{array}{l}\text { Disputes between project } \\
\text { stakeholders }\end{array}$ & $\begin{array}{l}\text { Equal variances } \\
\text { assumed }\end{array}$ & 2.138 & 0.146 & -2.432 & 124 & 0.016 & -0.321 & 0.132 \\
\hline
\end{tabular}

clearance/readiness of construction site involves the coordination among subcontractors in the finishing phase, so it is easy to understand when the contractors/subcontractors emphasize this factor more than the owners/consultants.

\section{Discovering Underlying Relationships among Construction Failure Factors to Stakeholder Coordinating Performance in the Finishing Phase of High-Rise Building Projects}

The 30 CFFs were then employed for factor analysis. The various tests for the appropriateness of factor analysis were performed. As a result, 14 CFFs were ignored because they did not pass such tests. That is, if either communalities or their factor loadings in, at least, a component are not greater than certain values, the variables should be ignored and factor analysis should be repeated from the first step. Each variable's communality, representing the amount of variance accounted for the factor solution for the variable, should be equal to, or greater than, 0.5 to have enough explanation [41]. As recommended in Hair et al. [41], with a sample size of this research around 126-factor, loading for each factor should exceed 0.5. Moreover, items had to display a 0.3 loading difference with any other factor to ensure discriminant validity [42].

The remaining 16 CFFs are appropriate for factor analysis. The value of Bartlett test of sphericity is 934.379 and the associated significance level is small $(p \leq 0.001)$. These suggest that the population correlation matrix is not an identity matrix [41]. The correlation matrix shows that all CFFs have a significant correlation at the $5 \%$ level. It implies that the deletion of any CFFs is unnecessary. The value of the Kaiser-Meyer-Olkin is 0.729 , which is satisfactory for factor analysis [41]. The varimax rotation of principal axis factoring extracts four main factors with eigenvalues greater than one (Table 5).

The main factors and their associated CFFs are labelled for convenience as follows: factor 1 is traditional adversarial relationship (TAR), factor 2 is poor project planning and organization (PPO), factor 3 is incompetent parties (IP), and factor 4 is delays of parties toward construction works (DP). The description of the main factors is also shown in Figure 3. The discussion of the main factors is provided in the following sections.

5.1. Traditional Adversarial Relationship (TAR). This factor group consists of dishonesty between project stakeholders (F24), regular transfer/replacement of key personnel (F25), lack of respect and trust between project stakeholders (F23), and lack of commitment from project stakeholders (F10). These issues were clearly caused by the relationship of the involved parties in the project implementation. Traditional adversarial relationship will significantly affect the overall objectives of the project. The relationship among parties can be enhanced or broken based on the coordination [43, 44]. Therefore, disrespect, untruthfulness, or resignation are contributing factors that affect the synchronization in a project. Besides, lack of reliance honesty and responsibility from one of the stakeholders can put them on the blacklist of other stakeholders [45].

The contractor's replacement of key staff, or groups of skilled craftsmen with less experienced ones during the construction phases, leads to poor coordination and distrust between the parties. To work with new people, it always takes a long time to make everything under control. For that matter, such replacement may affect the phase progress, thereby, the overall progress of the project.

Disrespectful and untruthful are unavoidable in the finishing phase of the construction projects. Such disagreement may arise from poor engagement from previous projects or in the implementation of existing projects that are not well coordinated. As a result, the owner may lose trust in the contractor, or the main contractor loses credibility with their subcontractors in cooperation on future projects. 
TABLE 5: The results of the factor analysis.

\begin{tabular}{|c|c|c|c|c|}
\hline Main factors & Eigenvalue & $\begin{array}{l}\text { Percentage of } \\
\text { variance }(\%)\end{array}$ & Construction failure factors & $\begin{array}{l}\text { Factor } \\
\text { loading }\end{array}$ \\
\hline \multirow{4}{*}{$\begin{array}{l}\text { Traditional adversarial relationship } \\
\text { (TAR) }\end{array}$} & \multirow{4}{*}{4.685} & \multirow{4}{*}{18.302} & F24. Dishonesty between project stakeholders & 0.897 \\
\hline & & & F25. Regular transfer/replacement of key personnel & 0.830 \\
\hline & & & $\begin{array}{l}\text { F23. Lack of respect and trust between project } \\
\text { stakeholders }\end{array}$ & 0.771 \\
\hline & & & F10. Lack of commitment from project stakeholders & 0.768 \\
\hline \multirow{4}{*}{$\begin{array}{l}\text { Poor project planning and } \\
\text { organization (PPO) }\end{array}$} & \multirow{4}{*}{2.276} & \multirow{4}{*}{16.794} & F18. Overlapping construction sequences & 0.787 \\
\hline & & & F16. Poor planning and scheduling & 0.768 \\
\hline & & & F17. Improper construction methods of contractors & 0.755 \\
\hline & & & $\begin{array}{l}\text { F19. Insufficient communication between project } \\
\text { stakeholders }\end{array}$ & 0.735 \\
\hline \multirow{4}{*}{ Incompetent parties (IP) } & \multirow{4}{*}{1.916} & \multirow{4}{*}{16.304} & $\begin{array}{l}\text { F1. Lack of capability of owner's project } \\
\text { management unit }\end{array}$ & 0.858 \\
\hline & & & F7. Consultants' lack of capability & 0.810 \\
\hline & & & F5. Design errors and omissions & 0.779 \\
\hline & & & F8. Contractors' lack of experience and competence & 0.700 \\
\hline \multirow{4}{*}{$\begin{array}{l}\text { Delays of parties toward } \\
\text { construction works (DP) }\end{array}$} & \multirow{4}{*}{1.597} & \multirow{4}{*}{14.066} & $\begin{array}{l}\text { F4. Delays in approving documents from } \\
\text { consultants/owner representatives }\end{array}$ & 0.777 \\
\hline & & & $\begin{array}{c}\text { F14. Delays in handing over works between } \\
\text { contractors }\end{array}$ & 0.689 \\
\hline & & & F21. Delays in problem-solving from owner & 0.673 \\
\hline & & & $\begin{array}{l}\text { F20. Handover of unclear/unready construction } \\
\text { grounds to other contractors }\end{array}$ & 0.635 \\
\hline
\end{tabular}

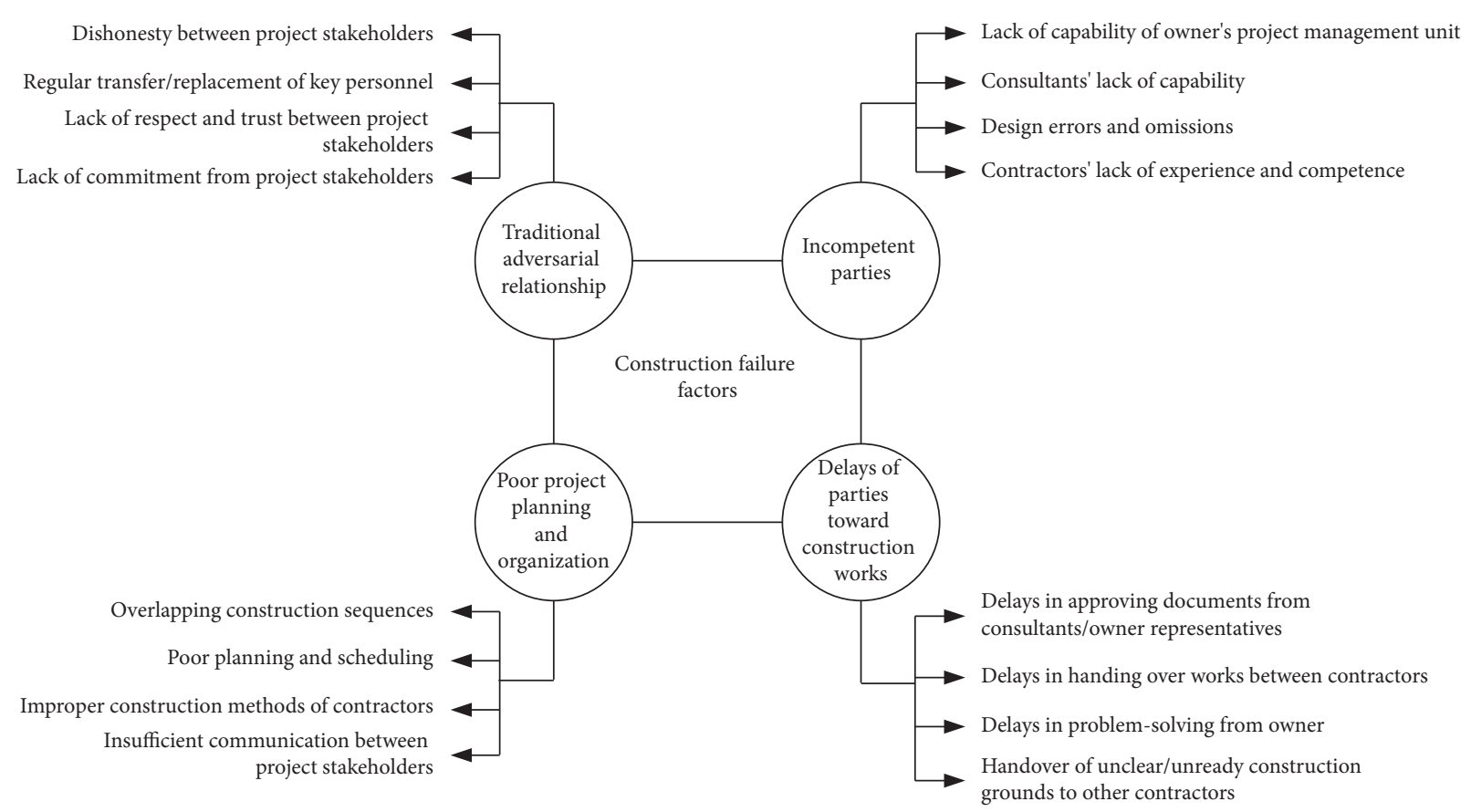

FIGURE 3: The main factors of construction failure factors to stakeholder coordinating performance in the finishing phase of high-rise building projects.

5.2. Poor Project Planning and Organization (PPO). The factor group is made up of overlapping construction sequences (F18), poor planning and scheduling (F16), improper construction methods of contractors (F17), and insufficient communication between project stakeholders (F19). The execution plan and project organization play an important role in a construction project, especially during the finishing phase of high-rise buildings. Construction experts convince that poor planning or unconstructive organization is one of the important factors leading to the failure of the project. This statement is consistent with the failure factor analysis in previous studies [3, 46]. For example, research by Nguyen and Chileshe [3] identified the most important failure factor that is "disregard of the 
significance of the project planning process and poor project planning." Indeed, the poor master program will definitely cause a lot of difficulties in the coordination planning of the stakeholders in each stage and workplace. The works of contractors, subcontractors, or teams may overlap, interrupt, split, or postpone each other, especially in situations where many different teams work in the same apartment or workplace [13]. In addition, the communication between the parties involved during this period also greatly affects the individual plans of the parties, causing undue disputes [47]. Improper communication results in unnecessary side jobs such as redesign, rework, and even construction accidents, which in turn contributes to coordination failure among stakeholders of construction projects [4].

5.3. Incompetent Parties (IP). This group consists of lack of capability of owner's project management unit (F1), consultants' lack of capability (F7), design errors and omissions (F5), and contractors' lack of experience and competence (F8). These failures are clearly due to the lack of capabilities of the participating agencies such as project management consulting units, design consultants, and contractors. Obviously, this leads to a direct impact on the quality, the coordination of the parties involved, the progress, profitability, and safety of the project.

First, the lack of capability of consultants may lead to the project losing control and delay in progress. This argument is consistent with the study of Le-Hoai et al. [48]. A consultant may then not be able to control the quality of the main contractor/subcontractors, nor the materials and equipment at the site. The consultant's control work is not only based on quality control, but also on the integration and matching of the parties' progress properly. Therefore, the ability of the consultant at the project is very important and directly affects stakeholders coordinating performance of high-rise building projects.

In addition, the capacity of the design consultants and the construction contractors are critical factors that affect the performance of the project; for example, an incompetent design consultant can make design mistakes which results in project delay or tardy progress [48]. In fact, design errors and omissions lead to consequences that the contractors will send numerous requests for information (RFIs) or send requests for approval (RFAs) to the design consultants, and then owners need to clarify uncertain information in the design. After that, the contractors will spend loads of time waiting for the response from the design consultants, which resulted in project progress being delayed. In case there are several errors in design, the contractor needs to redo the work many times, greatly affecting the quality and progress of the project $[49,50]$.

Besides, contractors' lack of experience and competence is also a reason leading to the project's failure. Choosing main contractors and subcontractors based on relationships or accepting nominated subcontractors from the owner without tight control can lead to negative consequences on project progress, quality, and cost of the construction project $[37,51]$. Another reason is that the main contractor has used too many subcontractors/suppliers as well as many teams to do their works [4], resulting in a loss control of stakeholder coordinating performance of construction high-rise projects.

5.4. Delays of Parties toward Construction Works (DP). Included in this factor are delays in approving documents from consultants/owner representatives (F4), delays in handing over works between contractors (F14), handover of unclear/unready construction grounds to other contractors (F20), and delays in problem-solving from the owner (F21). In any construction high-rise project, the finishing phase involves multiple stakeholders with the simultaneous implementation of different work items, which can be considered one of the most complex phases. Delay of the parties was the main reason leading to the failure of coordination performance between the parties during this period.

Delays in approving construction method documents, shop drawings, or releases of too many nonconformance reports (NCRs) from the owners/consultants can greatly affect the progress of the project. In addition, delays in problem-solving on site from the owner/consultant can affect not only the progress but also participating contractors. The consequence is significant impacts on the procurement process, construction progress of structural parts, MEP, and finishing works [52].

During the finishing phase, the plan of handing over the ground in this period is very complex, such as between the main contractors, subcontractors, and nominated subcontractors or between structure, MEP, and finishing contractors [11]. Subcontractors are affected by delays in the handover of premises from previous subcontractors, such as the increasing costs of storing equipment and supplies, as well as the increasing costs of the construction teams and their participant engineers. Also, the handover of unclean premises leads to wasted time and additional costs for other subcontractors who must clean up the premises of the previous contractors [14]. As a result, delays in the handover of the workplace leads to difficulty in stakeholders coordinating performance.

\section{Conclusions}

This study identified thirty CFFs to stakeholder coordinating performance in the finishing phase of high-rise building projects. Overall, all respondents agreed that "contractors' lack of experience and competence," "overlapping construction sequences," and "consultants' lack of capability" were the three most significant CFFs to stakeholder coordinating performance, while "unreasonable pressure from consultants and owner/owner representatives," "unforeseen accidents during construction," and "privacy policies of project stakeholders" were the two least significant CFFs. The respondents from the contractors/subcontractors generally rank CFFs higher than the owners/consultants.

The underlying relationships among CFFs were discovered under the four main factors, namely, (1) traditional 
adversarial relationship, (2) poor project planning and organization, (3) incompetent parties, and (4) delays of parties toward construction works. The traditional adversarial relationship accounted for the greatest variance (18.302\%) among all the factors, which indicated its level of significance and its contribution to leading a poor coordination performance among stakeholders. This implies that the stakeholders need to have a good relationship with each other, thereby improving their coordinating performance.

This study fills the gap in knowledge by identifying CFFs as well as their underlying relationships to stakeholder coordinating performance in the finishing phase of high-rise building projects. The study has given some implications for practitioners. Specifically, stakeholders should move towards a cooperative relationship. The cooperative relationship will improve honesty, respect, trust, and commitment among stakeholders. Therefore, approving documents, handing over works, problem-solving, and so on among stakeholders can be accelerated. As a result, the stakeholder coordinating performance will also be improved. Another implication is that owners should not select consultants and contractors with the lowest bid, which can result in selecting unqualified consultants and contractors. Consequently, problems such as design errors and omissions, poor planning and scheduling, and improper construction methods can arise during project implementation. This will lead to a poor coordinating performance between stakeholders. The results of factor analysis can be using a checklist before the start of the finishing phase. Stakeholders can foresee the CFFs to the coordinating performance so that they can come up with solutions to avoid and overcome them.

Despite the achievement of the objectives, this study has some limitations to its conclusions. The study was conducted in the context of Vietnam; therefore, the findings may not be generalized to other geographical locations. Nevertheless, it could be useful to similar studies in other countries for international comparison. Future research can collect data from different geographical locations to generalize results. Moreover, research can be performed to discover the interrelationships among the four factors identified in this study or assess the impacts of CFFs to stakeholder coordinating performance on the project performance.

\section{Data Availability}

The data used to support the findings of this study are available from the corresponding author upon request.

\section{Conflicts of Interest}

The authors declare no conflicts of interest regarding the publication of this paper.

\section{Acknowledgments}

This research was funded by Ho Chi Minh City University of Technology-VNU-HCM under Grant no. T-KTXD-201914.

\section{References}

[1] I. Basari, "“Estimation risk of high rise building on contractor," IPTEK," Journal of Engineering, vol. 3, no. 2, pp. 29-34, 2017.

[2] Y. Gamil and I. Abdul Rahman, "Assessment of critical factors contributing to construction failure in Yemen," International Journal of Construction Management, vol. 20, no. 5, pp. 429-436, 2018.

[3] T. P. Nguyen and N. Chileshe, "Revisiting the construction project failure factors in Vietnam," Built Environment Project and Asset Management, vol. 5, no. 4, pp. 398-416, 2015.

[4] Y. Gamil, I. Abdul Rahman, S. Nagapan, and N. Alemad, "Qualitative approach on investigating failure factors of Yemeni mega construction projects," MATEC Web of Conferences, vol. 103, pp. 03002-03006, 2017.

[5] I. S. Damoah and D. K. Kumi, "Causes of government construction projects failure in an emerging economy," International Journal of Managing Projects in Business, vol. 11, no. 3, pp. 558-582, 2018.

[6] V. R. Montequin, S. M. Cousillas, V. Alvarez, and J. Villanueva, "Success factors and failure causes in projects: analysis of cluster patterns using self-organizing maps," Procedia Computer Science, vol. 100, pp. 440-448, 2016.

[7] S. Trangkanont and C. Charoenngam, "Critical failure factors of public-private partnership low-cost housing program in Thailand," Engineering, Construction and Architectural Management, vol. 21, no. 4, pp. 421-443, 2014.

[8] C. Eastman, P. Teicholz, R. Sacks, and K. Liston, BIM Handbook-A Guide to Building Information Modeling for Owners, Managers, Designers, Engineers, and Contractors, John Wiley \& Son, Inc., Hoboken, NJ, USA, 2011.

[9] R. Retana, Implementation Feasibility of a Digital Nervous System (DNS) for the Construction Industry: For Efficient and Effective Information Management across the Project Lifecycle, Middlesex University, London, UK, 2016.

[10] B. Titarenko, A. Hasnaoui, R. Titarenko, and L. Buzuk, "Project risk management in the construction of high-rise buildings," E3S Web of Conferences, vol. 33, pp. 03074-03079, 2018.

[11] I. Brodetskaia, R. Sacks, and A. Shapira, "Stabilizing production flow of interior and finishing works with reentrant flow in building construction," Journal of Construction Engineering and Management, vol. 139, no. 6, pp. 665-674, 2013.

[12] R. Sacks, O. Seppänen, V. Priven, and J. Savosnick, "Construction flow index: a metric of production flow quality in construction," Construction Management and Economics, vol. 35, no. 1-2, pp. 45-63, 2017.

[13] I. Brodetskaia, R. Sacks, and A. Shapira, "A workflow model for systems and interior finishing works in building construction," Construction Management and Economics, vol. 29, no. 12, pp. 1209-1227, 2011.

[14] B. T. Kalsaas, "Further work on measuring workflow in construction site production," in Proceedings of IGLC 201220th Conference of the International Group for Lean Construction, San Deigo, CF, USA, January 2012.

[15] I. D. Tommelein, D. R. Riley, and G. A. Howell, "Parade game: impact of work flow variability on trade performance," Journal of Construction Engineering and Management, vol. 125, no. 5, pp. 304-310, 1999.

[16] A. S. Chang and F.-Y. Shen, "Coordination needs and supply of construction projects," Engineering Management Journal, vol. 21, no. 4, pp. 44-57, 2009. 
[17] T. Hai, A. Yusof, S. Ismail, and L. Wei, “A conceptual study of key barriers in construction project coordination," Journal of Organizational Management Studies, vol. 2012, pp. 1-14, 2012.

[18] D. D. d. Saram and S. M. Ahmed, "Construction coordination activities: what is important and what consumes time," Journal of Management in Engineering, vol. 17, no. 4, pp. 202-213, 2001.

[19] K. N. Jha and K. C. Iyer, "Critical determinants of project coordination," International Journal of Project Management, vol. 24, no. 4, pp. 314-322, 2006.

[20] K. N. Jha and S. Misra, "Ranking and classification of construction coordination activities in Indian projects," Construction Management and Economics, vol. 25, no. 4, pp. 409-421, 2007.

[21] K. C. Lam, A. G. F. Gibb, and W. D. Sher, "An analysis of building procurement factors affecting coordination of building services," in Proceedings of Annual ARCOM Conference, vol. 13, pp. 83-92, Cambridge, UK, September 1997.

[22] K. W. Andy NG and D. F. A. Price, "Causes leading to poor site coordination in building projects," Organ. Technol. Manag. Constr. an Int. J.vol. 2, no. 2, pp. 167-172, 2010.

[23] W. S. Alaloul, M. S. Liew, and N. A. W. A. Zawawi, "Identification of coordination factors affecting building projects performance," Alexandria Engineering Journal, vol. 55, no. 3, pp. 2689-2698, 2016.

[24] W. S. Alaloul, M. S. Liew, and N. A. BWA Zawawi, "A framework for coordination process into construction projects," MATEC Web of Conferences, vol. 66, p. 00079, 2016.

[25] R. Nallathiga, H. D. Shaikh, T. F. Shaikh, and F. A. Sheik, "Factors affecting the success/failure of road infrastructure projects under," Journal of Construction Engineering and Project Management, vol. 7, no. 4, pp. 1-12, 2017.

[26] D. I. Ikediashi, S. O. Ogunlana, and A. Alotaibi, "Analysis of project failure factors for infrastructure projects in Saudi Arabia: a multivariate approach," Journal of Construction in Developing Countries, vol. 19, no. 1, pp. 35-52, 2014.

[27] P. Papaioannou and M. Peleka, "Recent experience on success and failure stories from funding large transportation projects in Greece," in Proceedings 1st International Conference on Funding Transportation Infrastructure, Alberta, Canada, August 2006.

[28] O. O. Alao and G. O. Jagboro, "Assessment of causative factors for project abandonment in Nigerian public tertiary educational institutions," International Journal of Building Pathology and Adaptation, vol. 35, no. 1, pp. 41-62, 2017.

[29] E. O. Adebisi, S. O. Ojo, and O. O. Alao, "Assessment of factors influencing the failure and abandonment of multistorey building projects in Nigeria," International Journal of Building Pathology and Adaptation, vol. 36, no. 2, pp. 210-231, 2018.

[30] I. S. Damoah, I. Tingbani, D. K. Kumi, C. C. Akwei, and I. O. Amoako, "Factors influencing school building construction projects abandonment," International Journal of Construction Management, pp. 1-16. in press, 2019.

[31] G. Ofori, "Challenges of construction industries in developing countries: lessons from various countries," in Proceedings of 2nd International Conference on Construction in Developing Countries: Challenges Facing the Construction Industry in Developing Countries, vol. 5, no. 24, pp. 15-17, Gaborone, November 2000.

[32] N. H. El-sokhn and A. A. E. Othman, "Project failure factors and their impacts on the construction industry: a literature review," in Proceedings of 10th International Conference on
Civil and Architecture Engineering, pp. 1-20, Cairo, Egypt, May 2014.

[33] M. Y. Alhashemi, Critical Success \& Failure Factors for Public Private Partnership Projects in the UAE, British University in Dubai, Dubai, UAE, 2008.

[34] M. Z. A. Majid and R. McCaffer, "Assessment of work performance of maintenance contractors in Saudi Arabia," Journal of Management in Engineering, vol. 13, no. 5, p. 91, 1997.

[35] A. A. G. Hassanein and H. M. F. Afify, "Risk management practices of contractors: a case study of power station projects in Egypt," Journal of Financial Management of Property and Construction, vol. 12, no. 3, pp. 164-179, 2007.

[36] M. A. Hossain and D. K. H. Chua, "Overlapping design and construction activities and an optimization approach to minimize rework," International Journal of Project Management, vol. 32, no. 6, pp. 983-994, 2014.

[37] N. D. Long, S. Ogunlana, T. Quang, and K. C. Lam, "Large construction projects in developing countries: a case study from Vietnam," International Journal of Project Management, vol. 22, no. 7, pp. 553-561, 2004.

[38] A. S. Faridi and S. M. El-Sayegh, "Significant factors causing delay in the UAE construction industry," Construction Management and Economics, vol. 24, no. 11, pp. 1167-1176, 2006.

[39] M. Sambasivan and Y. W. Soon, "Causes and effects of delays in Malaysian construction industry," International Journal of Project Management, vol. 25, no. 5, pp. 517-526, 2007.

[40] P. W. Ihuah and A. M. Benobo, "An assessment of the causes and effects of abandonment of development projects on real property values in Nigeria," International Journal of Research in Applied, Natural and Social Sciences, vol. 2, no. 5, pp. 25-36, 2014.

[41] J. F. Hair, W. C. Black, B. J. Babin, and R. E. Anderson, Multivariate Data Analysis, Pearson Prentice Hall, Upper Saddle River, NJ, USA, 7 edition, 2010.

[42] N. Jabnoun and H. A. Hassan Al-Tamimi, "Measuring perceived service quality at UAE commercial banks," International Journal of Quality \& Reliability Management, vol. 20, no. 4, pp. 458-472, 2003.

[43] A. P. C. Chan and C. M. Yeong, "A comparison of strategies for reducing variations," Construction Management and Economics, vol. 13, no. 6, pp. 467-473, 1995.

[44] A. H. Van De Ven, "On the nature, formation, and maintenance of relations among organizations," Academy of Management Review, vol. 1, no. 4, pp. 24-36, 1976.

[45] A. Feige, H. Wallbaum, and S. Krank, "Harnessing stakeholder motivation: towards a Swiss sustainable building sector," Building Research \& Information, vol. 39, no. 5, pp. 504-517, 2011.

[46] S. Z. S. Tabish and K. N. Jha, "Success traits for a construction project," Journal of Construction Engineering and Management, vol. 138, no. 10, pp. 1131-1138, 2012.

[47] P. I. Cakmak and E. Cakmak, "An analysis of causes of disputes in the construction industry using analytical hierarchy process (AHP)," Procedia-Social and Behavioral Sciences, vol. 109, pp. 183-187, 2013.

[48] L. Le-Hoai, Y. D. Lee, and J. Y. Lee, "Delay and cost overruns in Vietnam large construction projects: a comparison with other selected countries," KSCE Journal of Civil Engineering, vol. 12, no. 6, pp. 367-377, 2008.

[49] P. E. D. Love, "Influence of project type and procurement method on rework costs in building construction projects," 
Journal of Construction Engineering and Management, vol. 128, no. 1, pp. 18-29, 2002.

[50] P.-E. Josephson, B. Larsson, and H. Li, "Illustrative benchmarking rework and rework costs in Swedish construction industry," Journal of Management in Engineering, vol. 18, no. 2, pp. 76-83, 2002.

[51] T. Y. Lo, I. W. Fung, and K. C. Tung, "Construction delays in Hong Kong civil engineering projects," Journal of Construction Engineering and Management, vol. 132, no. 6, pp. 636649, 2006.

[52] S. A. Assaf and S. Al-Hejji, "Causes of delay in large construction projects," International Journal of Project Management, vol. 24, no. 4, pp. 349-357, 2006. 